\title{
EVALUASI PENGENDALIAN PENJUALAN PRODUK PLASTIK UNTUK MENGURANGI KERUGIAN
}

\author{
Elizabeth Tiur Manurung \\ eliz@unpar.ac.id \\ Paulina Permatasari \\ Arthur Purboyo \\ Levithia Rinas \\ Universitas Katolik Parahyangan \\ J1. Ciumbuleuit No.94, Hegarmanah, Kec. Cidadap, Kota Bandung, Jawa Barat 40141
}

received: 10/6/2020; revised: 19/10/2020; approved: 28/10/2020

\begin{abstract}
Internal control review towards the revenue cycle is required to evaluate the effectiveness and efficiency of the existing management in order to support the achievement of company goals, and provide recommendations to allow corrective actions. These should be taken in order to review the role of internal control in increasing sale performance. This research used descriptive study method which could help to think systematically about various variables on a particular situation, to provide ideas for further research and to make simple decisions from the research that was done. Data collection techniques conducted were literature study and field study at Bandung Plastic company. Based on the result of internal control analysis, it was discovered that internal control set by the company will help company to handle loss of bad debt expenses, avoid fictitious sales, reduce improper sales target, reduce re-delivery cost, reduce erroneous task, and reduce environmental pollution.
\end{abstract}

Keywords: internal control; effectiveness; revenue cycle; loss on sales of products

\begin{abstract}
Abstrak
Penelaahan pengendalian internal terhadap siklus pendapatan diperlukan untuk menilai efektivitas dan efisiensi pengelolaan manajemen dalam mendukung pencapaian tujuan perusahaan, dan memberikan rekomendasi tindakan korektif sehingga diharapkan penilaian pengendalian internal dapat berperan dalam meningkatkan kinerja penjualan. Peneliti menggunakan metode studi deskriptif. Metode ini dapat membantu berpikir secara sistematis mengenai berbagai aspek dalam situasi tertentu, memberikan gagasan untuk penelitian lebih lanjut, dan membuat keputusan sederhana dari penelitian yang telah dilakukan, sedangkan teknik pengumpulan data yang dilakukan yaitu studi literatur dan studi lapangan di perusahaan Plastik Bandung. Berdasarkan hasil analisis atas pengendalian internal, dapat disimpulkan bahwa pengendalian internal membantu perusahaan dalam menangani kerugian piutang tidak tertagih, menghindarkan penjualan fiktif, mengurangi target penjualan yang tidak tercapai, mengurangi biaya pengiriman kembali, mengurangi kesalahan melakukan tugas, dan mengurangi polusi lingkungan.
\end{abstract}

Kata Kunci: pengendalian internal; efektivitas; siklus pendapatan; kerugian penjualan 


\section{PENDAHULUAN}

Terjadinya goncangan besar dalam perekonomian dunia, karena adanya krisis ekonomi global, yang disebabkan oleh perang dagang antara Amerika dan China, telah berdampak besar pada perekonomian Indonesia. Melemahnya daya beli di negara lain telah menurunkan jumlah ekspor kita ke luar negeri, dan hal ini menyebabkan kelesuan ekonomi di dalam negeri (Kompas, 02.03.17:17). Hal ini juga mengakibatkan persaingan dunia usaha di dalam negeri semakin tajam, karena harus mempertahankan target penjualan saat terjadi kondisi kelesuan ekonomi.

Kondisi persaingan yang sangat tajam, menyebabkan terjadinya penurunan Laba perusahaan, sehingga perusahaan harus mencari cara untuk dapat tetap melakukan penjualan semaksimal mungkin agar dihasilkan laba yang maksimal pula (Arens, et. al, 2017). Hal ini terjadi pada semua jenis perusahaan termasuk juga pada perusahaan yang memproduksi plastik.

Selain kompetisi yang sangat tajam, pabrik plastik sering diserang pula dengan munculnya isu tentang pencemaran lingkungan yang sangat parah yang diakibatkan sampah plastik (CnbcIndonesia.com, 2019). Hal ini terjadi disebabkan oleh penggunaan produk plastik secara tidak ramah lingkungan. Namun sekarang, kesadaran masyarakat telah meningkat, karena di berbagai tempat, masyarakat dengan giat berupaya mengurangi penggunaan kantong plastik sekali pakai, dan berusaha mengganti media plastik dengan berbagai media lain.

Mengatasi pencemaran lingkungan akibat sampah plastik, diperlukan kontribusi semua pihak, yang mengupayakan solusi dan mengelola sampah plastik yang ramah lingkungan (Lingkunganhidup.co, 2019). Alasan ini telah meningkatkan komitmen perusahaan untuk tetap menjalankan operasinya dengan lebih ramah lingkungan dengan memproduksi produk plastik yang dapat didaur ulang. Penelitian Chaffee dan Yoros (2010) mengemukakan keunggulan produk plastik, yaitu hemat energi dalam memproduksinya dibandingkan saat memproduksi kertas, logam atau produk kaca.

Pada era kompetisi usaha yang tajam ini, para pelaku usaha dituntut dapat meningkatkan produktivitasnya melalui efisiensi operasi serta mengembangkan potensi perusahaan. Operasi perusahaan seharus nya lebih difokuskan pada nilai tambah yang dapat dihasilkan dan mengurangi aktivitas yang tidak menghasilkan nilai tambah apalagi yang akan mengakibatkan kerugian bagi perusahaan. Hal ini berlaku pula pada aktivitas penjualan perusahaan.

Aktivitas penjualan perusahaan merupakan salah satu elemen yang sangat penting karena menghasilkan pendapatan bagi perusahaan. Penjualan merupakan salah satu fungsi dari pemasaran yang menjadi unsur penentu dalam pencapaian tujuan perusahaan. Pendapatan yang diperoleh dari penjualan seharusnya seluruhnya dapat diterima dengan utuh. Agar aktivitas penjualan dapat dikendalikan dengan baik, sehingga dapat dihindarkan adanya pemborosan serta kerugian lainnya, maka diperlukan pengendalian internal untuk meyakinkan bahwa penjualan telah dilakukan secara efektif dan efisien (Arens, at. al, 2017). Hal ini sesuai dengan kesimpulan penelitian Koesoema (2013) yang menyatakan bahwa karena sangat pentingnya penjualan, maka perlu diawasi melalui efektifnya system pengendalian internal penjualan. Dengan demikian yang dimaksud dengan pengendalian dalam penelitian ini adalah Pengendalian internal.

Pengendalian internal yang diterapkan dalam perusahaan perlu pula dievaluasi setiap periodik untuk mengidentifikasi kelemahan yang muncul, sehingga dapat dilakukan perbaikan. Seperti hasil penelitian Gunawan (2019), menyatakan bahwa evaluasi pengendalian internal penjualan plastik pada UD Kudu Plastik Mojokerto, telah berhasil meminimalkan risiko kerugian yang muncul seperti risiko transaksi fiktif dan risiko kesalahan pengiriman barang.

Umumnya fungsi penjualan dilaksanakan oleh divisi penjualan, dan didalamnya terdapat keterkaitan antara fungsi persediaan, fungsi pengiriman, dan fungsi yang menangani Kas. Apabila dalam melaksanakan aktivitas penjualan terdapat berbagai kelemahan, maka kelemahan tersebut dapat menjadi indikasi bahwa pengendalian internal khususnya untuk fungsi penjualan belumlah efektif (Arens, at. al, 2017).

Penyelenggaraan pengendalian internal atas penjualan haruslah efektif agar penjualan terhindar dari berbagai kelemahan yang dapat menimbulkan kerugian bagi perusahaan. Serta komitmen perusahaan yang tinggi dalam memproduksi plastik daur ulang telah mendorong dan menjadi alasan dilakukannya penelitian ini, dengan tujuan untuk mengevaluasi pengendalian internal aktivitas penjualan, sehingga kerugian dalam penjualan dapat dikurangi dan dihindarkan, agar laba perusahaan dapat ditingkatkan serta seluruh pendapatan dapat diterima dengan utuh dan lengkap.

Motivasi dilakukannya penelitian ini ingin memecahkan berbagai masalah yang dirangkum sebagai berikut: (1) Bagaimanakah implementasi Pengendalian internal pada siklus penjualan di perusahaan; (2) Apakah kekuatan pengendalian internal penjualan dapat mengurangi dan menghindarkan kerugian yang muncul pada aktivitas penjualan.

Tujuan didirikannya perusahaan adalah untuk memperoleh laba yang optimal. Penelitian Manurung (2018) menguraikan bahwa Laba merupakan semua penghasilan perusahaan selama periode tertentu setelah dikurangi semua biaya nya. Sehingga laba merupakan hal yang sangat penting bagi perusahaan, karena dapat digunakan untuk meningkatkan skala usaha perusahaan, meningkatkan produktivitas, sehingga perusahaan dapat mempertahankan operasinya dan dapat mencapai sustainability usahanya. Laba perusahaan dapat dicapai 
melalui aktivitas penjualan perusahaan. Menurut Soelistyoningrum (2011), laba yang dihasilkan selama suatu periode tertentu, menunjukkan kinerja manajemen dalam mengelola kekayaan asset perusahaan.

Sedangkan menurut Subramanyam dan Wild (2014), Laba adalah cerminan pengendalian kepada pemegang ekuitas untuk periode bersangkutan, sementara pospos dalam laporan merinci bagaimana laba didapat. Laba (earnings) ataupun laba bersih (net income) mengindikasikan pula profitabilitas perusahaan.

Laba merupakan gambaran mengenai kinerja yang dicapai dari aktivitas operasi perusahaan selama suatu periode tertentu (William, et. al, 2015). Jumlah laba dapat dijadikan indikator bagi para pemangku kepentingan untuk menilai sejauh mana kinerja manajemen dalam mengelola perusahaan. Laba tercipta dari pendapatan dikurangi biaya-biaya yang melekat didalamnya, artinya semakin besar biaya yang dikeluarkan tentunya akan mempengaruhi laba yang akan diperoleh perusahaan, termasuk bila terjadi kerugian yang harus ditanggung maka dampaknya akan mengurangi jumlah laba. Oleh karena itu setiap aktivitas perusahaan haruslah didukung oleh pengendalian internal yang efektif agar diperoleh laba yang optimum.

Menurut Diana \& Lilis (2011), proses bisnis dalam kegiatan penjualan meliputi: (1) Pemesanan barang oleh konsumen; (2) Pengiriman barang kepada konsumen; (3) pengiriman tagihan kepada konsumen; (4) Perusahaan menerima pelunasan kas dari konsumen.

Susanto \& Meiryani (2019), Siklus Pendapatan merupakan satu seri aktivitas bisnis dan aktivitas memproses informasi atas transaksi yang berulang untuk menghasilkan barang dan jasa sampai penagihan Kas atas penjualan tersebut. Empat aktivitas utama dalam siklus pendapatan adalah Sales order, pengiriman barang, piutang, dan penagihan Kas. Sistem informasi akuntansi ini haruslah didesain untuk memaksimalkan efisiensi penjualan. Dan pengendalian internal di dalamnya diterapkan untuk mengurangi Piutang tidak tertagih, mengurangi kerugian atas kecurian persediaan dan Kas.

Jenis penjualan dapat dikelompokkan menjadi dua, yaitu (1) Penjualan Tunai - yang mana barang atau jasa baru akan diserahkan oleh penjual kepada pembeli, bila pembeli telah membayar barang yang dibelinya; (2) Penjualan kredit - penjualan ini diakui sebagai penjualan bila order dari pelanggan telah dipenuhi dengan pingiriman barang, pelanggan tidak langsung membayar pembeliannya, oleh karena itu untuk suatu periode tertentu perusahaan memiliki piutang kepada pelanggannya (William, et. al, 2015).

Tidak semua perusahaan yang melakukan aktivitas penjualan, memiliki proses bisnis yang sama. Karakteristik barang yang dijual, pilihan kegiatan usahanya, cara penjualan yang dipilih perusahaan apakah secara tunai, kredit ataupun penjualan kontrak, serta budaya usahanya akan mempengaruhi proses bisnis perusahaan tersebut. Proses bisnis yang berbeda akan mengakibatkan berbedanya prosedur penjualan yang diterapkan perusahaan, sehingga akibatnya dokumen dan catatan yang digunakan perusahaan juga berbeda.

Uraian di atas menjelaskan bahwa penjualan merupakan kegiatan penting perusahaan yang melibatkan pembeli dan penjual, di mana penjual akan mencari dan mempengaruhi pembeli serta memberikan petunjuk pada pembeli, agar terjadi sebuah kesepakatan untuk penyerahan hak kepemilikan barang atau jasa dari penjual ke pembeli demi keuntungan kedua pihak. Seperti pada penelitian Khin, et. al, (2015) yang mengungkapkan bahwa terdapat hubungan yang signifikan antara penjualan kredit dan laba perusahaan asal diikuti dengan pengendalian penjualan yang efektif.

Nurbiyati dan Machfoedz (2005) menguraikan tahapan-tahapan dalam penjualan sebagai berikut: (1) Prospek - Prospek adalah orang yang dinilai mempunyai kemampuan untuk membeli di mana orang tersebut telah menunjukkan rasa tertarik pada produk atau jasa yang ditawarkan. Perusahaan harus mencari prospek baru, untuk meningkatkan penjualan dan menggantikan konsumen lama yang tidak lagi membeli produk; (2) Perencanaan Pra-Penjualan - merupakan perencanaan kunjungan penjualan yang dianggap merupakan dasar keberhasilan, mengetahui informasi tentang konsumen menjadi kunci atas keberhasilan penjualan; (3) Presentasi Penjualan - merupakan kunjungan penjualan kepada konsumen, yang menjelaskan tentang fungsi dan manfaat produk. Prospek memandang informasi ini sebagai solusi atas problem yang mereka hadapi. (4) Mengatasi keberatan prospek - keberatan yang dikemukakan oleh prospek merupakan pernyataan bahwa prospek tidak bersedia untuk membeli produk. Kebertan ini dapat disimpulkan menjadi empat macam, yaitu pertama keberatan terselubung, kedua tidak memberi jawaban yang jelas, ketiga tidak memerlukan produk yang ditawarkan, dan keempat karena alasan keuangan; (5) Menutup Penjualan - merupakan proses membantu prospek dalam mengambil keputusan yang mendatangkan manfaat untuk mereka, membantu mengambil keputusan dengan menawarkan suatu produk untuk mereka beli.

Arens, et. al. (2017) berpendapat bahwa Sistem Pengendalian Internal terdiri dari kebijakan-kebijakan dan prosedur-prosedur yang didesain untuk meyakinkan bahwa manajemen dapat mencapai tujuan perusahaan. Sehingga dapat dikatakan bahwa pengendalian internal merupakan sebuah alat yang digunakan untuk mencapai tujuan perusahaan. Tujuan diterapkannya pengendalian internal oleh perusahaan, adalah untuk: (1) menghasilkan Laporan keuangan yang dapat dipercaya; (2) mencapai efektivitas dan efisiensi atas operasi yang dilakukan perusahaan; (3) agar perusahaan mentaati semua peraturan baik di internal maupun peraturan eksternal. Pada penelitian Harmen dan Machdar (2012) dikemukakan bahwa Pengendalian internal meliputi rencana organisasi, 
kebijakan-kebijakan yang ditetapkan untuk mengamankan harta perusahaan, menguji ketepatan data akuntansi, dan mendorong ditaatinya peraturan-peraturan. Tujuan pengendalian poin dua yaitu agar operasi perusahaan efektif dan efisien misalnya pada aktivitas pernjualan, juga sesuai dengan penelitian Ifurueze (2013) yang menyatakan bahwa Aktivitas penjualan kredit yang efektif dan efisien akan mendorong tercapainya laba yang diharapkan. Sebaliknya penelitian Anggana (2019) menyatakan bahwa bila terdapat kelemahan atas pengendalian penjualan, maka akan mengakibatkan terjadinya error atau fraud, contoh nya terjadi kesalahan pengiriman barang.

Pengendalian internal merupakan bagian-bagian dalam perusahaan yang bekerja bersama untuk memastikan bahwa tujuan organisasi dapat dicapai. Unsur-unsur dari pengendalian internal berupa prosedur, kebijakan, alat-alat, atau tindakan yang saling berhungan untuk mencapai tujuan organisasi. Bila pengendalian internal kurang efektif, dapat mengakibatkan kerugian bagi perusahaan. Oleh karenanya, perusahaan harus menyelenggarakan pengendalian internal yang baik juga dalam akitivas penjualan agar terhindar dari kerugian. Pengendalian internal secara periodik harus dievaluasi agar efektif, seperti pada penelitian Heinze, et. al, (2010) dalam mengevaluasi pengendalian internal salah satunya dapat menggunakan Benchmark dalam bentuk checklist, yang berguna untuk menilai pengendalian internal penjualan. Checklist tersebut juga dapat digunakan untuk mencari solusi dalam situasi kesulitan ekonomi serta Audit yang diperlukannya.

\section{METODE}

Metode penelitian yang digunakan dalam penelitian ini adalah Studi Deskriptif. Metode ini, tidak hanya memberikan gambaran mengenai fenomena yang terjadi pada objek penelitian, namun lebih jauh akan memberikan penjelasan, membuat interpretasi berdasarkan hasil pengolahan data, membuat prediksi, serta mendapatkan makna dan implikasi dari suatu masalah yang diteliti. Hal ini sejalan dengan tujuan penelitian ini, yaitu mengevaluasi pengendalian internal penjualan perusahaan untuk memberikan usulan rekomendasi yang dapat mengurangi kerugian pada aktivitas penjualan, sehingga seluruh pendapatan dari transaksi penjualan dapat diterima oleh perusahaan secara utuh dan lengkap.

Metode Deskriptif memiliki cakupan yang luas yaitu dapat menggunakan pendekatan kuantitatif maupun kualitatif. Dalam penelitian ini digunakan pendekatan kualitatif, artinya pengumpulan data diutamakan yang bersifat kualitatif, sedangkan data kuantitatif tetap digunakan namun hanya merupakan data penunjang untuk melakukan analisa. Umumnya studi deskriptif tidak membuat kesimpulan untuk tujuan men-generalisasi, artinya hasil yang didapatkan dari penelitian tidak dapat disamakan untuk semua objek yang sejenis. Namun metode ini dapat memberikan penjelasan secara rasional tentang hasil simpulan yang didapatkan dari penelitian.

Pengumpulan data observasi \& wawancara kepada para karyawan perusahaan. Objek penelitian yang digunakan adalah variabel pengendalian internal pada aktivitas penjualan di perusahaan yang bergerak dalam bidang manufaktur dengan memproduksi plastik yang dapat didaur ulang. Perusahaan juga mengharapkan bahwa setiap konsumen yang menggunakan produk plastik dapat mengurangi penggunaan plastik yang sifatnya sekali pakai. Perusahaan sangat mendukung komitmen masyarakat di berbagai tempat yang telah mencanangkan untuk mengurangi penggunaan plastik yang sekali pakai, serta membuat produk plastik yang dapat didaur ulang, hal ini dilakukan untuk mengurangi kerusakan yang diakibatkan oleh sampah plastik. Unit penelitian yang digunakan adalah Perusahaan Plastik Bandung yang dijelaskan dalam uraian di bawah ini.

Perusahaan Plastik Bandung didirikan pada Tahun 2010, pada awalnya perusahaan bergerak di bidang pembuatan logo untuk toko-toko yang berbasis online yang bergerak dalam usaha pakaian. Usaha yang dipilih tersebut sejalan dengan maraknya toko berbasis online yang saat itu marak juga.

Melihat antusias yang tinggi dari para pelanggannya, maka perusahaan meluaskan usahanya dengan merambah inovasi baru yaitu pengaplikasian desain yang dibuatnya untuk dicetak ke berbagai produk plastik seperti standing pouch, lunch box, sendok dan garpu plastik, gelas plastik, dan sebagainya. Pada Tahun 2016, operasi usaha perusahaan diperluas kembali dengan menambahkan produk plastik berjenis polos yang dijual kepada pelanggannya, baik agen maupun toko.

Visi dari Perusahaan Plastik Bandung ini adalah menjadi distributor plastik yang terdepan, baik dalam hal ketersediaan barang maupun tenaga kerja. Sedangkan misi perusahaan adalah Perusahaan berusaha terus menerus membuka wilayah distribusi dan berupaya untuk semakin memberikan kemudahan kepada pelanggan. Perusahaan menawarkan dan menjual produk dan jasanya baik secara offline maupun melalui media elektronik seperti Instagram, Facebook, dan Tokopedia. Beberapa pelanggan nya antara lain Hush Puppies, Chatime, The Executive, dan sebagainya.

\section{HASIL}

Berdasarkan hasil wawancara dan observasi langsung ke perusahaan Plastik Bandung, diperoleh pemahaman tentang struktur organisasi perusahaan dan prosedur pada aktivitas penjualan (Gambar 1).

Berdasarkan observasi langsung di perusahaan, prosedur aktivitas penjualan dimulai saat staf Salesman marketing menawarkan produk kepada pelanggan, kemudian diterima order dari pelanggan baik melalui 
Salesman, maupun melalui bagaian penjualan. Persetujuan atas order tersebut dilakukan oleh Pemilik. Bagian administrasi printing akan mendesain order pelanggan tersebut sesuai dengan yang dikehendaki pelanggan, hasil dari desain produk akan dicetak oleh staf printing dan selanjutnya dilakukan packaging terhadap pesanan tersebut.

Produk yang kedua, adalah Produk plastik polosan ditangani oleh divisi plastik polosan, dalam hal ini melakukan distribusi kepada Agen dan toko malalui staf ekspedisi, membuat invoice kepada konsumen, serta menyusun laporan keuangan. Divisi plastik polosan dibantu oleh staf plastik polosan yang bertugas melakukan packaging terhadap pesanan konsumen, kemudian produk dikirim ke konsumen melalui staf ekspedisi, dan staf ekspedisi juga yang menerima sisa pelunasan dari konsumen. Namun pembayaran dari konsumen umumnya diterima langsung oleh Pemilik perusahaan.

Perusahaan telah menggunakan sistem terkomputerisasi untuk menangani seluruh transaksi yang terjadi di dalam perusahaan, baik kegiatan penjualan, pembelian, pembayaran gaji, pergudangan, maupun transaksi Hutang dan piutang. Sehingga laporan keuangan yang dikerjakan oleh Divisi plastik polosan dapat dihasilkan dalam waktu yang tepat karena jarang telat, serta lebih akurat.

Dari uraian di atas, dalam Divisi plastik polosan terdapat dua bagian, yaitu Admin plastik polosan dan Staf Plastik polosan. Admin plastik polosan, bertugas (1) melakukan stock opname barang; (2) memesan barang ke supplier; (3) melakukan distribusi barang ke toko dan agen; (4) membuat invoice untuk menagih kepada konsumen; (5) dan menyusun Laporan keuangan. Sedangkan Staf Plastik polosan, bertugas (1) menerima barang dari supplier, dan (2) melakukan packaging terhadap pesanan konsumen. Pada dasarnya perusahaan tidak memiliki dokumen tertulis baik job description, maupun prosedur dan kebijakan penjualan. Informasi tentang prosedur ini diperoleh dari pemberitahuan perusahaan secara lisan.

Jenis penjualan yang dilakukan oleh perusahaan ada dua, yaitu (1) penjualan tunai, dan (2) penjualan kredit. Kas atas penjualan tunai akan langsung diterima saat barang dikirim kepada pelanggan, sedangkan pada penjualan kredit maka kas akan diterima saat jatuh tempo pembayaran setelah periode jangka waktu kredit yang disepakati, sehingga saat barang dikirim akan muncul Piutang pelanggan. Karena Kas hasil penjualan kredit akan diterima di masa yang akan datang, maka muncul risiko kemungkinan piutang tidak dapat ditagih, misalnya karena pelanggan kesulitan keuangan sehingga tidak mampu membayar. Hasil observasi menunjukkan bahwa terdapat Piutang yang tidak dapat ditagih sebesar Rp. 100 juta.

Perusahaan memiliki divisi ekspedisi sendiri yang menangani khusus pesanan yang akan dikirimkan kepada seorang pelanggan dalam jumlah yang besar dan dikirim masih dalam area Kota Bandung. Namun bila terdapat pengiriman barang sesuai pesanan yang berasal dari luar kota misalnya pesanan melalui Tokopedia dalam jumlah kecil maka seringkali digunakan jasa ekspedisi seperti JNE atau JNT. Hasil observasi menunjukkan bahwa terdapat beberapa kali kesalahan pengiriman barang kepada pelanggan karena alamat pelanggan yang sudah berubah.

Hasil penelitian juga menemukan bahwa prediksi penjualan yang dilaksanakan perusahaan, dilakukan melalui penyusunan Anggaran target Penjualan dan Biaya penjualan. Target penjualan Bulanan yaitu berkisar Dua milyar Rupiah per bulan, namun data pada Tahun 2019 menunjukkan target penjualan tidak tercapai. Selisih tidak tercapainya target penjualan bulanan selama periode Tahun 2019 yaitu sebesar -167 atau sebesar $-16,7 \%$. Selisih target penjualan dapat dilihat pada Tabel 1.

Selain target penjualan yang harus dicapai, perusahaan juga menyampaikan informasi bahwa terdapat anggaran Biaya tetap perbulan sekitar Rp. 30 juta; yaitu untuk biaya operasional dan gaji pegawai, namun biaya tersebut dapat lebih besar dari anggarannya dikarenakan adanya lembur dan hal-hal yang tidak terduga.

\section{PEMBAHASAN}

Berdasarkan uraian prosedur penjualan di atas, kemudian dilakukan penilaian dan evaluasi atas pengendalian internal penjualan, seperti hasil penelitian Iswara (2016) yang menyatakan bahwa penilaian pengendalian internal cukup berperan dalam meningkatkan produktivitas fungsi penjualan. Evaluasi pengendalian menghasilkan dua kemungkinan yaitu hal-hal yang mendukung efektivitas pengendalian, dan hal-hal yang kurang mendukung dalam tercapainya efektivitas pengendalian penjualan tersebut, sehingga jumlah pendapatan yang seharusnya diterima tidak dapat secara utuh diterima oleh perusahaan.

Produk Plastik yang dihasilkan perusahaan berbahan dasar plastik daur ulang. Hal ini ditujukan untuk mengurangi pencemaran lingkungan akibat sampah plastik, sesuai meningkatnya kesadaran masyarakat untuk terus mengupayakan solusi dan mengelola sampah plastik yang ramah lingkungan. Alasan ini telah meningkatkan komitmen perusahaan untuk tetap menjalankan operasinya dengan lebih ramah lingkungan dengan memproduksi produk plastik yang ramah lingkungan. Dalam penelitian Chaffee dan Yoros (2010) disebutkan bahwa produk plastik lebih ramah lingkungan dibandingkan dengan produk kertas, logam dan kaca.

Terdapat pemisahan fungsi atas aktivitas produksi yang dilakukan oleh perusahaan untuk produk desain plastik. Yaitu fungsi yang menangani order dilaksanakan oleh Salesman atau bagian penjualan, 
persetujuan order dilakukan langsung oleh pemilik dengan mempertimbangkan bahwa order tersebut dapat dilaksanakan karena kuantitas dan model yang dipesan telah memenuhi ketentuan perusahaan, dan bagian administrasi printing sebagai pelaksana produksi serta staf printing sebagai fungsi packaging. Adanya pemisahan fungsi ini telah dapat menghindarkan adanya penjualan fiktif karena ada monitoring langsung dari pemilik, yang mencocokan dokumen penjualan dengan dokumen bagian printing, serta Kas yang diterima. Seperti pada jurnal CFI (2015), menyatakan bahwa pengendalian yang memadai atas penjualan kredit adalah dengan adanya pemisahan fungsi atas persetujuan order pesanan, dokumen pengiriman, dan tagihan yang akurat kepada pelanggan. Hal yang sama dikemukakan pula pada penelitian Zone (2017).

Admin plastik polosan yang membuat invoice kepada pelanggan atas transaksi penjualan yang terjadi, sementara Kas dari pelanggan diterima langsung oleh pemilik, telah menghasilkan kuatnya pengendalian karena Kas langsung dipegang oleh pemilik. Dan bila pelanggan membayar sisa pelunasannya melalui staf ekspedisi hal inipun tetap menghasilkan pengendalian yang memadai karena pelanggan akan meminta bukti lunas dari admin, sehingga bagian ekspedisi tidak dapat melakukan kecurangan.

Otorisasi terjadinya penjualan dan penerimaan Kas langsung oleh pemilik juga telah menghasilkan pengendalian untuk menghindarkan kecurangan, yaitu walaupun terdapat dalam satu bagian yang sama, namun tetap terdapat pemisahan fungsi antara fungsi pencatatan penjualan, dengan penanganan barang secara fisik kepada pelanggan karena pemilik akan mencocokkan data penjualan yang diotorisasi dengan Kas yang diterimanya. Seperti penelitian Zone (2017), menyatakan bahwa Otorisasi order penjualan kredit yang memadai dapat menghindarkan terjadinya kecurangan misalnya yang menimbulkan piutang macet.

Bagian ekspedisi hanya mengirim barang atas order yang jumlahnya besar dan di area Kota Bandung, sedangkan untuk order dari luar kota yang jumlahnya relatif kecil akan dikirim melalui jasa ekspedisi misalnya JNE. Hal ini menghasilkan pengendalian dalam bentuk efisiensi biaya pengiriman barang yang lebih efektif, yang akan menghasilkan peningkatan laba perusahaan.

Anggaran Penjualan dan Biaya yang dimiliki oleh perusahaan, merupakan salah satu alat pengendalian yang baik. Perusahaan dapat mengontrol operasinya berdasarkan anggaran yang telah ditetapkan. Operasi penjualan dapat dievaluasi apakah sesuai dengan anggarannya, dan bila ada yang tidak sesuai maka dilakukan perbaikan sebagai follow-up sehingga aktivitas penjualan dapat terkendali dan kerugian dapat dihindarkan. Adanya anggaran penjualan sebagai salah satu alat untuk menganalisa aspek keuangan dalam aktivitas penjualan dapat meningkatkan penjualan perusahaan, hal ini disebutkan oleh Ariyanto \& Yanti
(2012) pada kesimpulan hasil penelitiannya.

Laporan keuangan terkomputerisasi. Laporan keuangan yang dibuat oleh divisi plastik polosan telah dibuat menggunakan software komputer. Komputer digunakan untuk menangani seluruh transaksi yang terjadi di perusahaan, mencatat transaksi dan secara otomatis memposting ke dalam buku besar, lalu membuat rekapnya sampai menghasilkan laporan keuangan yang menyeluruh, lengkap dan akurat sesuai transaksi yang diinput ke dalam komputer. Dihasilkannya laporan keuangan yang terkomputerisasi memungkinkan pemilik untuk mengevaluasi operasi perusahaan sehingga pemilik dan pihak lain yang menggunakan laporan tersebut dapat membuat keputusan yang tepat. Hal ini seperti yang dinyatakan dalam kesimpulan penelitian Harmen dan Machdar (2012) bahwa penggunaan komputer untuk menyiapkan laporan keuangan dapat menghindarkan kesalahan atas penanganan transaksi, tingkat ketelitiannya tinggi, dan akurat.

Perusahaan tidak memiliki dokumen tertulis atas job description, prosedur dan kebijakan penjualan. Perusahaan hanya memberitahu secara lisan. Job description, prosedur dan kebijakan seharusnya dibuat secara tertulis agar ada kejelasan fungsi-fungsi dalam menjalankan tugas. Selain itu, harus diperbaharui secara berkala jika ada perubahan. Dan seperti hasil penelitian Wahyuningsih, et. al, (2016) yang menyatakan bahwa aktivitas penjualan pada PDAM Kabupaten Malang efektif karena selalu berpedoman pada kebijakan, sistem, dan prosedur yang telah ditetapkan perusahaan. Walaupun perusahaan tidak membuat dokumen secara tertulis karena perusahaan beranggapan bahwa job description, prosedur dan kebijakan akan lebih mudah dimengerti jika disampaikan secara lisan dan langsung dipraktekkan oleh para karyawan. Dengan tidak adanya job description mengakibatkan pengendalian internal dalam perusahaan menjadi kurang efektif dimana batas tanggung jawab menjadi kurang jelas, selain itu karyawan baru akan kesulitan dalam mengerti seluruh prosedur dan kebijakan yang ada sehingga dapat memperbesar peluang terjadinya kesalahan yang mengakibatkan kerugian. Analisis mitigasi pengendalian internal atas kelemahan tersebut dapat dilihat pada Gambar 2.

Terdapat pekerjaan rangkap dalam perusahaan. Admin plastik polosan dan admin plastik printing merangkap sebagai bagian pembelian bahan baku, administrasi, gudang dan juga accounting. Seharusnya terdapat pemisahan tugas antar bagian tersebut karena setiap bagian memiliki uraian tugas dan tanggungjawab yang berbeda. Perusahaan tidak melakukan pemisahan tugas karena pemilik berpikir dapat memonitor langsung kegiatan pembeliannya melalui pencocokan Kas keluar untuk pembayaran pembelian langsung dari pemilik, sehingga perangkapan fungsi tersebut dimaksudkan untuk menekan biaya tenaga kerja dan juga pemilik beranggapan bahwa dengan banyaknya pekerja akan membuat tingkat produktivitas seseorang turun. Adanya 
indikasi kecurangan baik yang disengaja maupun yang tidak disengaja sehingga dapat menyebabkan kerugian bagi perusahaan, walaupun seharusnya fungsifungsi tersebut harus dipisahkan. Pemisahan fungsi merupakan pengendalian penjualan yang memadai dikemukakan dalam penelitian Zone (2017). Analisis mitigasi pengendalian internal atas perangkapan fungsi tersebut dapat dilihat pada Gambar 3.

Perusahaan beberapa kali mengalami piutang tidak tertagih dimana pelanggan susah untuk dihubungi atau sering mengundur waktu pelunasan. Seharusnya ketusan pemberian kredit didasarkan pada analisa yang akurat, serta terdapat kontrak perjanjian pre-order antara pelanggan dengan penjual. Perusahaan belum memiliki aturan yang ketat mengenai kontrak perjanjian preorder antara pelanggan dengan penjual. Dengan adanya piutang tidak tertagih, perusahaan mengalami kerugian karena arus kas yang terhambat dan menurun akibat tidak ada penerimaan kas yang masuk atas pelunasan piutang oleh pelanggan serta perusahaan juga sudah terlanjur mengeluarkan kas untuk membayar barang yang telah dipesan kepada supplier untuk memenuhi pesanan pelanggan.

Selanjutnya dari jurnal satu (Tabel 2) pada bagian debit, pos perkiraan Biaya Piutang tidak tertagih akan diposting ke dalam Laporan Laba Rugi sebagai unsur pengurang pada periode tersebut, akibatnya biaya bertambah besar dan Laba akan berkurang. Pengendalian yang diusulkan atas hal ini adalah adanya prosedur analisa kredit agar plafond batas pemberian kredit tidak dilanggar, dan pelanggan yang menunggak tidak diberikan kredit baru. Hal ini seperti yang diungkapkan dalam hasil penelitian Gunawan (2019). Analisis mitigasi pengendalian internal atas tidak tertagihnya piutang tersebut dapat dilihat pada Gambar 4.

Terjadi kesalahan pengiriman produk yang dipesan oleh pelanggan karen ada perubahan alamat pelanggan, sehingga produk tersebut tidak sampai di tangan pelanggan. Seharusnya Perusahaan memiliki databased yang berisi data pelanggan yang terbaru. Perusahaan jarang melakukan update terhadap data pelanggan. Selain itu, perusahaan juga mengalami biaya tambahan untuk pengiriman ulang. Menurut perusahaan biaya pengiriman ulang ditanggung oleh perusahaan, yang besarnya sesuai dengan kuantitas dan lokasi tujuan pengirimannya. Pada gilirannya, Biaya pengiriman ulang tersebut akan diposting ke dalam Laporan Laba Rugi yang menyebabkan menurunnya Laba perusahaan. Analisis mitigasi pengendalian internal atas kesalahan pengiriman produk dapat dilihat pada Gambar 5.

Setyabudi (2013) dalam hasil penelitiannya menyimpulan bahwa salah satu cara untuk menilai efektivitas dan efisiensi aktivitas penjualan adalah dengan menganalisa Selisih target penjualan. Karena persaingan yang sangat tajam, pada perusahaan Plastik Bandung terdapat Selisih negatif atas Target Penjualan seperti yang nampak pada Tabel 1 yang diuraikan sebelumnya, menunjukkan tidak tercapainya target penjualan perusahaan, dapat mengakibatkan timbulnya kerugian atas biaya yang harus dikeluarkan misalnya biaya tetap untuk gaji tetap kepala divisi plastik polosan, sesuai dengan hasil observasi dan wawancara, biaya tetap atas operasional dan biaya pegawai sebesar Rp. 30 juta. Oleh karena itu di masa depan harus diupayakan agar target penjualan bulanan tersebut dapat dicapai untuk mengoptimalkan biaya tetap tersebut. Menurut hasil penelitian Sari (2017), alasan tidak tercapainya target penjualan perusahaan salah satunya dikarenakan adanya perubahan dari pola konsumsi masyarakat, serta semakin banyaknya pesaing yang dihadapi perusahaan. Sedangkan Kurniawan (2019), menyatakan bahwa untuk meningkatkan penjualan agar sesuai target, dapat dilakukan melalui peningkatan kualitas produk dan memberi pelayanan yang baik kepada pelanggan. Penelitian Manurung (2019) menyatakan bahwa promosi yang memadai dapat meningkatkan penjualan seperti pada industri keramik. Analisis mitigasi pengendalian internal atas kelemahan tersebut dapat dilihat pada Gambar 6.

\section{KESIMPULAN}

Berdasarkan hasil evaluasi yang dilakukan terhadap siklus penjualan di Perusahaan Plastik Bandung, dapat disimpulkan bahwa pengendalian internal penjualan yang diterapkan di perusahaan Plastik Bandung sudah cukup memadai, hal ini dibuktikan dengan banyaknya pengendalian yang terindikasi misalnya (a) Produk plastik yang dihasilkan adalah plastik daur ulang serta adanya komitmen perusahaan untuk turut menghimbau konsumen untuk mengurangi penggunaan plastik sekali pakai, (b) Pemisahan fungsi antara penanganan order, persetujuan order, produksi, dan penerimaan Kas oleh pemilik sehingga dapat menghindarkan terjadinya penjualan fiktif, (c) sedangkan pengendalian atas produk plastik polosan yaitu invoice dibuat oleh Admin, penagihan dilakukan oleh bagian ekspedisi dan Kas diterima oleh pemilik, (d) penjualan telah ditunjang oleh bagian ekspedisi yang efisien baik dari segi biaya dan waktu, (e) terdapat Anggaran penjualan yang disusun oleh perusahaan sehingga bisa dijadikan alat pengawasan penjualan, (f) Laporan keuangan yang terkomputerisasi telah membantu pemilik untuk mengevaluasi aktivitas penjualannya dan melakukan perbaikan yang diperlukan.

Pengendalian internal dapat mengurangi kerugian atas kelemahan aktivitas penjualan, terutama dalam hal (a) kesalahan melakukan tugas oleh karyawan, (b) terhindarkannya penjualan fiktif, karena admin yang melakukan fungsi pembelian, gudang dan akuntansi langsung diawasi oleh pemilik melalui pencocokkan dokumen penerimaan barang dengan Kas yang dibayarkan kepada supplier, (c) analisa kredit yang lebih akurat dan kontrak perjanjian pre-order dapat 
mengurangi Piutang yang tidak tertagih, (d) databased pelanggan dapat mengurangi pengiriman yang salah alamat, (e) memperbaiki pelayanan kepada pelanggan dan kualitas produk serta komisi salesman akan dapat mengurangi tidak tercapainya target penjualan

\section{DAFTAR PUSTAKA}

Anggana, D. 2019. The Analysis of Control Activities of Credit Sales an Cash Receipt

Arens, A. A. Elder, R. J. Beasley, M. S, and Hogan, C. E. 2017. Auditing and Assurance Services. London: Pearson Education Limited

Ariyanto, S. and Juli Y. 2012. Audit Operasional atas siklus Pendapatan pada PT. New Inti Furnindo Cabang Bandung. Jurnal Repository Bina Nusantara Jakarta.

Chaffee, C\& Bernard R. Y. 2010. Life Cycle Assessment for Three Types of Grocery Bags - Recyclable plastic; Compostable, Biodegradable plastic, and Recycled, Recyclable paper. Article of Journal Boustead Consulting \& Associates ltd, 2010.

Diana dan Lilis S. 2011. Sistem Informasi Akuntansi: perancangan, proses, dan penerapan. Yogyakarta: Penerbit Andi.

Gunawan, I. A. 2019. Evaluasi Sistem Pengendalian Internal terhadap Siklus Penjualan UD Dagang Kudu Plastik Mojokerto. Jurnal Repository Universitas Katolik Wydia Mandala Surabaya. www.repository. wima.ac.id/17200/

Harmen, R. A. dan Nera M. M. 2012. Peranan Pengendalian Internal atas Penjualan, Piutang dan Penerimaan Kas dalam rangka Kegiatan operasi Perusahaan PT. Listex Prima. Institut Teknologi dan Bisnis Kalbe Jakarta. Jurnal JMA Vol 17 No 2, Okt-Nov 2012.

Heinze, T., Tim, K., John, L., Kent, S. 2010. Internal Control for the Revenue cycle: A Cheklist for the Consumer Product Industry. International Business and Economics Research Journal. August 2010 Vol 9, Number 8.

Ifurueze, M.S.K. 2013. The Impact of Effective Management of Credit Sales on Profitability and Liquidity of Food and Beverage Industries in Nigeria. Global Journal of Management and Business Research Vol 13 Issue 2 Version 1.0, 2013.

Iswara, D., Syafii, A. R. 2016. Penerapan Audit Operasional dalam Menilai Efisiensi dan Efektivitas Fungsi Penjualan Pada CV Anugerah Jaya Sidoarjo. Jurnal Universitas Bhayangkara Surabaya.

Journal of Corporate Financial Institute (CFI). 2015. Internal Control for Sales Class Transaction. corporatefinanceinstitute.com/resources/ knowledge/accounting/sales-and-collectioncycle/2015

Khin, E. W. S., Loong, C. K., Singh, G. 2015. Family Own Businesses Small \& Medium size of enterprises SME Credit Control credit Management. The South
East Asian Journal of Management Vol 9 No 1, 2015.

Koesoema, V. N. A. 2013. Analisis dan Perancangan Sistem Informasi Akuntansi PT. Rajawali Plastik pada Siklus Penjualan. Jurnal Repositori Unika Wydia Mandala Surabaya.

Kurniawan, K. 2019. Cara Meningkatkan Omzet Penjualan. www.projasaweb.com.

Lingkunganhidup.co/2019/sampah-plastik-indonesiadunia/

Manurung, E. T. 2019. The Effectiveness of Financing Model to Support Competitive Advantage in Ceramic Industry. Jurnal Riset Akuntansi Kontemporer (JRAK) Vol 11 No 2 (2019) Edisi Oktober pp. 48-53

Manurung, E. T. 2018. Meningkatkan Komitmen Karyawan melalui Employee Stock Ownership Program untuk Meningkatkan Kesejahteraan Karyawan. Jurnal Riset Akuntansi Kontemporer Vol 10 No 2 Edisi Oktober 2018. Pp. 49-57.

Nurbiyati T, \& Machfoeds M. 2005. Manajemen Pemasaran Kontemporer. Yogyakarta: KAYON

Sari, R. N. 2017. Pemeriksaan Operasional terhadap Aktivitas Penjualan untuk meningkatkan Efektivitas dan Efisiensi Penjualan Dodol (Studi Kasus PT. Hedinah Cipta Pratama). Jurnal Repositori Universitas Katolik Parahyangan.

Sekaran U., and Bougie R. 2016. Research Method for Business: a Skill-Building Approach. Chichester: John Wiley \& Sons.

Setyabudi, T. G. 2013. Audit Operasional Fungsi Penjualan untuk menilai Efisiensi dan Efektivitas Bagian Penjualan PT. Ladang Rizki Jaya Sentosa Surabaya. Jurnal Ilmu \& Riset Akuntansi Vol. 2 No. 4.

Soelistyoningrum, J. N. 2011. Pengaruh Pengungkapan Sustainability Report terhadap Kinerja Keuangan Perusahaan: Studi Empiris pada Perusahaan yang terdaftar di Bursa Efek Indonesia. Jurnal Akuntansi Universitas Dipenogoro, Semarang (2011).

Subramanyam K., \& Wild J.J. 2014. Analisa Laporan Keuangan. United Kongdom: A. John Wiley and Sons.

Susanto, A., Meiryani. 2019. Revenue cycle in Accounting Information Syatem. International Journal of Scientific \& Technology Research Vol 8, Issue 06, June 2019.

Wahyuningsih, N., Abdul, H., Retno W. 2016. Peranan Audit Operasional dalam Menunjang Efektivitas Penjualan (Studi Empiris pada Perusahaan Daerah Air Minum Kabupaten Malang). Jurnal Universitas Kanjuruhan Malang.

Williams JR., SF Haka, MS Bettner and JV Carcello. 2015. Financial and Managerial. Accounting: The Basis for Business Decision. 16th edition; Mc GrawHill EducationNew York. ISBN: 9780071220125.

Zone, Hahu. 2017. Internal Control for Accounts Receivable. Jurnal pada: Accountingtools.com/ articles/2017/5/15/accounts-receivable-controls. 


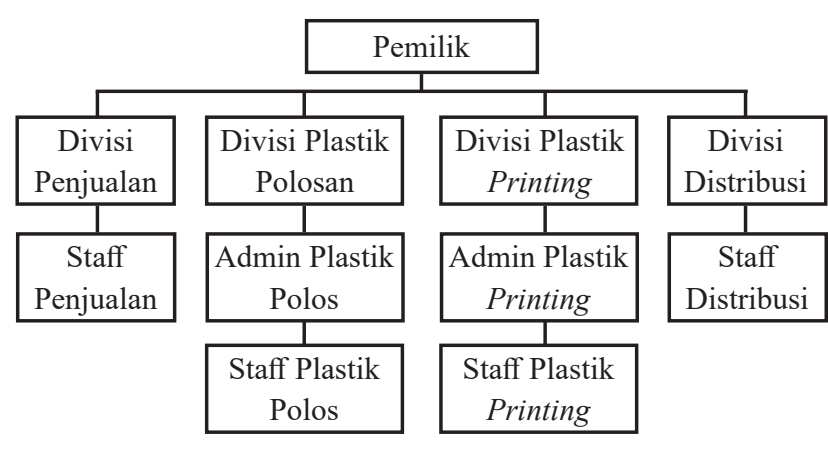

Sumber: Data perusahaan

Gambar 1. Struktur Organisasi Perusahaan Plastik Bandung

Tabel 1. Data Penjualan Perusahaan Plastik Bandung 2019

\begin{tabular}{llcc}
\hline & 2019 & Pencapaian Penjualan & Selisih dengan Target \\
\hline 1 & Januari & 792 & -208 \\
2 & Februari & 790 & -210 \\
3 & Maret & 1.102 & +102 \\
4 & April & 921 & -79 \\
5 & Mei & 1.172 & +172 \\
6 & Juni & 521 & -479 \\
7 & Juli & 826 & -174 \\
8 & Agustus & 885 & -115 \\
9 & September & 742 & -258 \\
10 & Oktober & 631 & -369 \\
11 & November & 820 & -180 \\
12 & Desember & 799 & -201 \\
\hline & Rata2 & 833 & -167 \\
\hline
\end{tabular}

Sumber: Data perusahaan

\begin{tabular}{|c|c|c|c|}
\hline $\begin{array}{l}\text { In d i k a s i } \\
\text { kelemahan: } \\
\text { Pro s e d u r } \\
\text { tidak terdo- } \\
\text { kumentasi }\end{array}$ & $\begin{array}{l}\text { Risiko po- } \\
\text { tensial: Salah } \\
\text { melakukan } \\
\text { tugas }\end{array}$ & $\begin{array}{l}\text { Mitigasi } \\
\text { Internal } \\
\text { Control: } \\
\text { dokumen- } \\
\text { tasikan }\end{array}$ & $\begin{array}{l}\text { Terhindar } \\
\text { dari keru- } \\
\text { gian karena } \\
\text { salah laku- } \\
\text { kan fung- } \\
\text { sinya }\end{array}$ \\
\hline
\end{tabular}

Gambar 2. Mitigasi Kelemahan Prosedur tidak terdokumentasi

\begin{tabular}{|c|c|c|c|}
\hline \begin{tabular}{|l} 
In d i k a s i \\
kelemahan: \\
Admin plas- \\
tik sebagai \\
bagian pem- \\
beli, gdg, Akt
\end{tabular} & $\begin{array}{l}\text { R i s i k o } \\
\text { potensial: } \\
\text { A d a n y a } \\
\text { pembelian } \\
\text { Fiktif }\end{array}$ & $\begin{array}{l}\text { M it ig a si } \\
\text { In t e r n a l } \\
\text { Contro } 1: \\
\text { pemisahan } \\
\text { fungsi: beli, } \\
\text { gudang, catat }\end{array}$ & $\begin{array}{l}\text { Terhindar } \\
\text { dari kerugian } \\
\text { y a n g } \\
\text { timbul dari } \\
\text { pembelian } \\
\text { fiktif }\end{array}$ \\
\hline
\end{tabular}

Gambar 3. Mitigasi Kelemahan atas Perangkapan Fungsi

Tabel 2. Jurnal Pencatatan Piutang tidak tertagih

1. Mencatat Biaya Piutang tidak Dr. Biaya Piutang tidak Tertagih tertagih melalui Penyisihan Piutang Cr. Penyisihan Piutang ragu-ragu

2. Penghapusan Piutang tidak Dr. Penyisihan Piutang raguTertagih sebesar Rp 100 juta ragu Rp 100 juta Cr. Piutang Rp 100 juta

\begin{tabular}{|c|c|c|c|}
\hline $\begin{array}{l}\text { In dik a si } \\
\text { kelemahan: } \\
\text { A d a n y a } \\
\text { Piutang tidak } \\
\text { tertagih }\end{array}$ & \begin{tabular}{|l} 
R i s i k o \\
Potensial: \\
K e rugian \\
k a r e n a \\
piutang tidak \\
tertagih
\end{tabular} & \begin{tabular}{|l} 
M i t i g a s i \\
I n t e r n a 1 \\
C o n t r o l: \\
A n a 1 i s a \\
kredit akurat \\
\& kontrak
\end{tabular} & $\begin{array}{l}\text { Terhindar } \\
\text { darikerugian } \\
\text { B i a y a } \\
\text { piutang tidak } \\
\text { t e r t a g i h } \\
\text { Rp.100jt }\end{array}$ \\
\hline
\end{tabular}

Gambar 4. Mitigasi Kelemahan atas Piutang Tidak Tertagih

\begin{tabular}{|c|c|c|c|}
\hline $\begin{array}{l}\text { In d i k a s i } \\
\text { kelemahan: } \\
\text { Salah alamat } \\
\text { Pengiriman }\end{array}$ & \begin{tabular}{|l|} 
R i s i k o \\
Potensial: \\
K erugian \\
pengiriman \\
ulang(jumlah \\
\& lokasi)
\end{tabular} & \begin{tabular}{|l|} 
M i t i g a s i \\
I n t e r n a l \\
c o n t r o l: \\
databased yg \\
dipelihara \& \\
update
\end{tabular} & $\begin{array}{l}\text { Terhindar } \\
\text { darikerugian: } \\
\text { Pengiriman } \\
\text { u } 1 \text { a } n \text { g } \\
\text { (jumlah \& } \\
\text { lokasi) }\end{array}$ \\
\hline
\end{tabular}

Gambar 5. Mitigasi Kelemahan atas Salah Pengiriman Produk

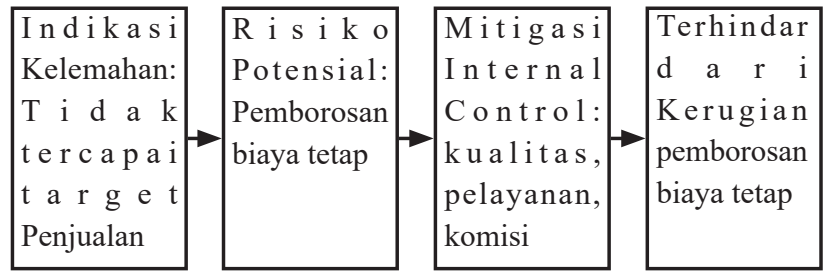

Gambar 6. Mitigasi Kelemahan atas tidak tercapainya Target Penjualan 